\title{
Is there a north-south divide in social class inequalities in health in Great Britain? Cross sectional study using data from the 2001 census
}

Tim Doran, Frances Drever, Margaret Whitehead

\begin{abstract}
Objective To examine individual social class inequalities in self rated general health within and between the constituent countries of Great Britain and the regions of England.

Design Cross sectional study using data from the 2001 national census.

Setting Great Britain.

Participants Adults aged between 25 and 64 in Great Britain and enumerated in the 2001 population census $(\mathrm{n}=25.6$ million).

Main outcome measures European age standardised rates of self rated general health, for men and women classified by the government social class scheme.

Results In each of the seven social classes, Wales and the North East and North West regions of England had high rates of poor health. There were large social class inequalities in self rated health, with rates of poor health generally increasing from class 1 (higher professional occupations) to class 7 (routine occupations). The size of the health divide varied between regions: the largest rate ratios for routine versus higher professional classes were for Scotland (2.9 for men; 2.8 for women) and London (2.9 for men; 2.4 for women). Women had higher rates of poor health compared to men in the same social class, except in class 6 (semi-routine occupations).

Conclusions A northwest-southeast divide in social class inequalities existed in Great Britain at the start of the 21st century, with each of the seven social classes having higher rates of poor health in Wales, the North East and North West regions of England than elsewhere. The widest health gap between social classes, however, was in Scotland and London, adding another dimension to the policy debate on resource allocation and targets to tackle the health divide.
\end{abstract}

\section{Introduction}

Reducing inequalities in health between socioeconomic groups is a government priority, with targets set at local and national levels. ${ }^{1-4}$ For NHS and social service agencies charged with meeting these targets, whether social inequalities in health are sharper in some regions of Britain than in others is of scientific and policy relevance. The $2001 \mathrm{UK}$ census contained questions on self rated general health, used a new classification of social class, and covered the whole population. We used these data to explore patterns in social inequalities in health at an individual level.

\section{Methods and results}

We took data from the 2001 UK census for England and Wales ${ }^{5}$ and Scotland. ${ }^{6}$ Census respondents were asked to rate their general health in the previous 12 months as "good," "fairly good," or "not good." We calculated European age-standardised rates of poor health ("not good" health category) by sex, social class, and region by the direct method. ${ }^{7}$ We calculated rate ratios between social classes by sex and region. ${ }^{8}$

The new national statistics socioeconomic classification is based on current occupation and employment status for both men and women. ${ }^{9}$ The seven main classes are based on responsibilities within the job, including degree of control over work rate and content and supervisory duties. An eighth class is for the long term unemployed and those who have never worked. Figures for class 8 are given only for completeness. Because of the scheme's occupational basis, relatively few people under the age of 25 and over 64 were classified into the seven main categories (54\% and $8 \%$ respectively). We therefore restricted the analyses to those aged 25 to 64 , of whom 85\% (25.6 million people) were classified into the seven main classes.

Large geographic inequalities in health existed across the country in 2001, with rates of poor health for men ranging from less than 49/1000 in the South East region to more than $80 / 1000$ in Wales and the North East (table 1). The range for women was from less than 52/1000 in the South East to more than $81 / 1000$ in Wales (table 2).

Within each region there were large social class inequalities in self rated health, with rates of poor health generally increasing from classes 1 (higher managerial and professional occupations) through to 7 (routine occupations). People in class 7 had rates of poor health double or more those of people in class 1. The exception to the step wise gradient in health was for women in class 6 , who had better health than the preceding class 5 women, though still worse than class 4 .

The health of people in each social class varied considerably depending on where they lived. For example, people in class 1 in the South East had much lower rates of poor health than those in the North East (rates of 28/1000 and 46/1000 for men; 36/1000 and $52 / 1000$ for women). Similarly, people in class 7 in the East of England had lower rates of poor health than those in Wales $(74 / 1000$ and $113 / 1000$ for men; $77 / 1000$ and $119 / 1000$ for women). Overall, people in all seven social classes in Wales fared badly, as did those in the North East and, to a lesser extent, the North West. In contrast, people in all social classes in the South East, and most classes in the east and the South West, had lower rates of poor health than the Great Britain average for their own class.

The size of the social inequalities in health varied between regions (table 3). Men in Scotland and London had almost threefold differences in rates of poor health

Table $A$ gives details of the new national statistics $\mathrm{P}+$ socioeconomic class scheme
Department of

Public Health,

University of

Liverpool,

Liverpool L69 3GB

Tim Doran

clinical lecturer in

public health medicine

Frances Drever

visiting senior

research fellow

Margaret

Whitehead

WH Duncan

professor of public

health

Correspondence to:

T Doran

timdoran@

liverpool.ac.uk

BMJ 2004;328:1043-5 
Table 1 European age standardised rate* (per 1000) of self reported health "not good," by social class (national statistics socioeconomic classification) and region for men aged 25-64, Great Britain, 2001

\begin{tabular}{|c|c|c|c|c|c|c|c|c|c|}
\hline & & 1 & 2 & 3 & 4 & 5 & 6 & 7 & 8 \\
\hline & $\begin{array}{l}\text { Classes } 1 \text { to } \\
7 \text { combined }\end{array}$ & $\begin{array}{l}\text { Higher managerial } \\
\text { and professional } \\
\text { occupations }\end{array}$ & $\begin{array}{l}\text { Lower managerial } \\
\text { and professional } \\
\text { occupations }\end{array}$ & $\begin{array}{l}\text { Intermediate } \\
\text { occupations }\end{array}$ & $\begin{array}{c}\text { Small } \\
\text { employers and } \\
\text { own account } \\
\text { workers }\end{array}$ & $\begin{array}{l}\text { Lower supervisory } \\
\text { and technical } \\
\text { occupations }\end{array}$ & $\begin{array}{l}\text { Semi-routine } \\
\text { occupations }\end{array}$ & $\begin{array}{c}\text { Routine } \\
\text { occupations }\end{array}$ & $\begin{array}{l}\text { Long term } \\
\text { unemployed and } \\
\text { never worked }\end{array}$ \\
\hline Great Britain & 63.7 & 34.9 & 49.0 & 64.5 & 65.2 & 74.5 & 87.0 & 93.5 & 196.7 \\
\hline Scotland & 68.8 & 34.9 & 51.0 & 68.5 & 66.6 & 77.9 & 92.5 & 100.4 & 203.1 \\
\hline Wales & $82.3 \dagger$ & $46.1 \dagger$ & $64.9 \dagger$ & $79.6 \dagger$ & $80.6 \dagger$ & $92.6 \dagger$ & $104.4 \dagger$ & $113.4 \dagger$ & $230.1 \ddagger$ \\
\hline England: & 62.2 & 34.4 & 48.0 & 63.4 & 64.2 & 73.0 & 85.4 & 91.4 & 193.8 \\
\hline North East & $81.2 \dagger$ & $43.2 \dagger$ & $64.9 \dagger$ & $75.8 \ddagger$ & $82.8 \dagger$ & $88.5 \ddagger$ & $98.0 \neq$ & $108.4 \ddagger$ & 184.2 \\
\hline North West & $75.7 \ddagger$ & $40.3 \ddagger$ & $58.6 \ddagger$ & $72.4 \ddagger$ & $77.0 \ddagger$ & $86.3 \ddagger$ & $99.3 \ddagger$ & $106.6 \ddagger$ & $217.8 \ddagger$ \\
\hline $\begin{array}{l}\text { Yorkshire and } \\
\text { Humber }\end{array}$ & 71.1‡ & $40.4 \ddagger$ & $53.9 \ddagger$ & 68.0 & 70.8 & 79.6 & 90.1 & 97.9 & 192.7 \\
\hline East Midlands & 63.7 & 35.9 & 49.7 & 65.3 & 63.5 & 73.2 & 82.0 & 86.6 & 184.0 \\
\hline West Midlands & 66.9 & 36.9 & 50.5 & 65.9 & 64.8 & 74.9 & 89.3 & 93.3 & 193.8 \\
\hline East & $52.0 \S$ & $31.3 \S$ & $41.0 \S$ & $54.0 \S$ & $56.3 \S$ & 60.01 & $73.4 \S$ & 74.79 & $175.4 \S$ \\
\hline London & 61.8 & 34.7 & 49.0 & 65.0 & 66.7 & 77.6 & 89.7 & 101.0 & 200.3 \\
\hline South East & 48.99 & $28.4 \S$ & 38.79 & $55.0 \S$ & $54.5 \S$ & $59.4 \uparrow$ & $72.8 \S$ & $76.3 \S$ & $176.3 \S$ \\
\hline South West & $57.3 \S$ & 32.8 & $44.9 \S$ & 61.4 & 60.8 & $65.4 \S$ & $76.2 \S$ & $82.4 \S$ & 190.8 \\
\hline No of people in class & 13348223 & 2292698 & 3345051 & 787060 & 1895421 & 1833532 & 1378590 & 1815871 & 468264 \\
\hline
\end{tabular}

*Standardised to European standard population.

Rate is $20 \%$ or more higher than the rate for Great Britain.

IRate is $10 \%$ or more higher than the rate for Great Britain.

§Rate is $10 \%$ or more lower than the rate for Great Britain.

IRate is $20 \%$ or more lower than the rate for Great Britain.

between classes 7 and 1 . For women, the regional variation was greater. Scotland had a rate ratio between classes 7 and 1 of 2.8, whereas the South West and East had much smaller health gaps (rate ratios of 1.8 and 1.9).

Noticeable inequalities between sexes in health by social class within and between regions existed. Rates of poor health were nearly always higher for women than for men in each region and each social class. The exception was for class 6 (semi-routine occupations), where women in every region had lower rates of poor health than for class 6 men in the same region. The largest sex difference for class 6 was in the North West, where rates of poor health were $15 \%$ lower for women than men. Conversely, the smallest sex difference was in London, where rates were $8 \%$ lower for women.

\section{Comment}

We found serious and consistent gradients in self rated poor health across the social spectrum in 2001 in each of the constituent countries of Great Britain and in every one of the nine regions of England. The north-south split was not neat, however. Wales and North East and North West England fared particularly badly, with high rates of poor health for every social class. Even for people in the same social class, their risks of poor health varied greatly depending on where they lived. Women in class 1 in Wales fared worse than women in class 4 in the South West, and men in class 4 in the North West fared worse than men in class 7 in the South East.

Table 2 European age standardised rate* (per 1000) of self reported health "not good," by social class (national statistics socioeconomic classification) and region for women aged 25-64, Great Britain, 2001

\begin{tabular}{|c|c|c|c|c|c|c|c|c|c|}
\hline & & 1 & 2 & 3 & 4 & 5 & 6 & 7 & 8 \\
\hline & $\begin{array}{c}\text { Classes } 1 \text { to } 7 \\
\text { combined }\end{array}$ & $\begin{array}{c}\text { Higher } \\
\text { managerial and } \\
\text { professional } \\
\text { occupations }\end{array}$ & $\begin{array}{c}\text { Lower } \\
\text { managerial and } \\
\text { professional } \\
\text { occupations }\end{array}$ & $\begin{array}{c}\text { Intermediate } \\
\text { occupations }\end{array}$ & $\begin{array}{c}\text { Small } \\
\text { employers and } \\
\text { own account } \\
\text { workers }\end{array}$ & $\begin{array}{c}\text { Lower } \\
\text { supervisory } \\
\text { and technical } \\
\text { occupations }\end{array}$ & $\begin{array}{l}\text { Semi-routine } \\
\text { occupations }\end{array}$ & $\begin{array}{c}\text { Routine } \\
\text { occupations }\end{array}$ & $\begin{array}{c}\text { Long term } \\
\text { unemployed } \\
\text { and never } \\
\text { worked }\end{array}$ \\
\hline Great Britain & 65.0 & 43.7 & 53.4 & 55.6 & 60.4 & 84.3 & 75.4 & 97.5 & 205.8 \\
\hline Scotland & 71.1 & 40.7 & 55.3 & 59.7 & 60.6 & $94.7 \ddagger$ & 82.2 & $114.4 \ddagger$ & $239.9 \ddagger$ \\
\hline Wales & $81.5 \dagger$ & $56.4 \dagger$ & $65.9+$ & $66.4 \dagger$ & $72.9 \dagger$ & $106.8 \dagger$ & $93.0 \dagger$ & $119.3 \dagger$ & $245.7 \ddagger$ \\
\hline England: & 63.5 & 43.4 & 52.5 & 54.7 & 59.6 & 81.8 & 73.5 & 94.2 & 200.5 \\
\hline North East & $78.5 \dagger$ & $52.4 \dagger$ & $62.5 \neq$ & $64.4 \ddagger$ & $77.5 \dagger$ & $101.6 \dagger$ & $85.0 \neq$ & $111.9 \ddagger$ & 216.0 \\
\hline North West & $74.4 \ddagger$ & $50.3 \ddagger$ & $59.4 \ddagger$ & $62.7 \ddagger$ & $71.4 \ddagger$ & $96.8 \neq$ & $84.0 \neq$ & $111.0 \ddagger$ & $232.7 \ddagger$ \\
\hline $\begin{array}{l}\text { Yorkshire and } \\
\text { Humber }\end{array}$ & 70.8 & $48.4 \ddagger$ & 57.5 & 58.6 & 65.9 & 88.9 & 78.9 & 100.2 & 215.7 \\
\hline East Midlands & 65.2 & 46.4 & 53.4 & 53.7 & 62.7 & 82.9 & 71.5 & 91.2 & 191.5 \\
\hline West Midlands & 68.4 & 46.2 & 56.0 & 55.7 & 63.9 & 83.0 & 78.3 & 97.6 & 210.3 \\
\hline East & $54.5 \S$ & 39.9 & $47.0 \S$ & $48.0 \S$ & $51.6 \S$ & $68.6 \S$ & $63.1 \S$ & $76.6 \S$ & 165.09 \\
\hline London & 65.3 & 42.8 & 55.4 & $61.3 \neq$ & 63.2 & 86.8 & $82.6 \neq$ & 104.5 & 201.5 \\
\hline South East & 51.81 & $36.3 \S$ & $44.0 \S$ & $46.7 \S$ & $49.0 \S$ & $68.1 \S$ & $62.6 \S$ & 77.01 & 163.49 \\
\hline South West & $57.7 \S$ & 44.0 & 49.6 & $50.0 \S$ & $53.2 \S$ & $72.7 \S$ & $65.7 \S$ & $80.5 \S$ & $180.3 \S$ \\
\hline No of people in class & 12289316 & 916255 & 3608370 & 2420206 & 748927 & 709918 & 2597337 & 1288303 & 747519 \\
\hline
\end{tabular}

${ }^{*}$ Standardised to European standard population.

thate is $20 \%$ or more higher than the rate for Great Britain.

tRate is $10 \%$ or more higher than the rate for Great Britain.

Rate is $10 \%$ or more lower than the rate for Great Britain. 
Table 3 Rate ratios for age standardised rates of "not good" self reported health of social classes 7 and 1 for people 25-64 by sex and region of Great Britain 2001

\begin{tabular}{llc} 
& \multicolumn{2}{c}{ Rate ratio (95\% confidence limit) } \\
\hline Great Britain & \multicolumn{1}{c}{ Men } & Women \\
\hline Scotland & $2.68(2.66$ to 2.70$)$ & $2.23(2.20$ to 2.26$)$ \\
\hline Wales & $2.88(2.80$ to 2.96$)$ & $2.81(2.69$ to 2.94$)$ \\
\hline England: & $2.46(2.38$ to 2.54$)$ & $2.12(2.00$ to 2.23$)$ \\
\hline North East & $2.66(2.64$ to 2.68$)$ & $2.17(2.14$ to 2.20$)$ \\
\hline North West & $2.51(2.41$ to 2.60$)$ & $2.14(2.00$ to 2.27$)$ \\
\hline Yorkshire and Humber & $2.65(2.59$ to 2.71$)$ & $2.21(2.13$ to 2.29$)$ \\
\hline East Midlands & $2.43(2.36$ to 2.49$)$ & $2.07(1.98$ to 2.16$)$ \\
\hline West Midlands & $2.42(2.35$ to 2.49$)$ & $1.97(1.87$ to 2.06$)$ \\
\hline East & $2.53(2.47$ to 2.59$)$ & $2.11(2.02$ to 2.21$)$ \\
\hline London & $2.39(2.33$ to 2.45$)$ & $1.92(1.84$ to 2.00$)$ \\
\hline South East & $2.91(2.85$ to 2.98$)$ & $2.44(2.37$ to 2.52$)$ \\
\hline South West & $2.69(2.63$ to 2.74$)$ & $2.12(2.05$ to 2.19$)$ \\
\hline
\end{tabular}

Wales and the northern parts of England were not, however, the regions with the largest social inequalities. Scotland and London had the widest health divides, even though rates of poor health for most social classes in those areas were close to the overall rates for Great Britain. The emergence of London and Scotland as regions with the sharpest social class inequalities in self rated general health adds another dimension to the policy debate on resource allocation to tackle the health divide. Have the English northerly regions started to escape the double jeopardy noted by Townsend in relation to mortality in the $1980 \mathrm{~s} ?^{10}$ Or does the outcome measure of self rated general health reveal a different aspect of population health from that of mortality used in these earlier studies? If so, what are the implications for current methods of resource allocation, which increasingly strive to incorporate measures of morbidity and quality of life in addition to mortality?

These and other questions need to be answered by further interrogation of the rich data source of the 2001 census database on which we based our study (see bmj.com).

Contributors: TD, FD, and MW conceived the idea for the analyses. TD and FD did the analyses. All authors interpreted the data, drafted and revised the paper, and approved the final version. $\mathrm{TD}$ and FD are guarantors.

\section{What is already known on this topic}

Social classifications used in studies to date have not been theoretically based, and measurement of the whole population's health has relied largely on mortality data

\section{What this study adds}

In 2001, there were large social class inequalities in self rated health in Great Britain, with rates of poor health increasing from class 1 (higher professional occupations) to class 7 (routine occupations) of the new national statistics socioeconomic classification

Rates of poor self rated health were highest for each of the seven social classes in Wales and the North East and North West of England. The widest health gaps between social classes, however, were in Scotland and London

Women generally had poorer self rated health than men, but in class 6 (semi-routine occupations) this pattern was reversed

Funding: None.

Competing interests: None.

Ethical approval: Not needed.

1 Acheson D, Barker D, Chambers J, Graham H, Marmot M, Whitehead M, eds. Report of the independent inquiry into inequalities in health. London: Staionery Office, 1998 .

2 Saving lives: our healthier nation. London: Stationery Office, 1999

Department of Health. Key NHS interventions to support the achievement of the national health inequalities target. London: DoH, 2003.

4 Department of Health. Tackling health inequalities: a programme for action. London: DoH, 2003. www.doh.gov.uk/healthinequalities (accessed 5 Apr 2004).

5 Office for National Statistics. Census 2001: CD supplement to the National report for England and Wales and key statistics for local authorities in England and Wales. London:OfNS, 2003.

6 General Register Office for Scotland. Scotland's census. www.groscotland.gov.uk/grosweb/grosweb.nsf/pages/censushm.

7 Acotand.gov.uk/grosweb/grosweb.nsf/pages/censushm.

8 Armitage P, Colton T. Encyclopedia of biostatistics. Chichester: Wiley, 1998. Armitage P, Berry G, Matl
Oxford: Blackwell, 2002.

9 ONS standard occupational classification 2000. Volume 1: Structure and description of unit groups. Volume 2: The coding index. London: Stationery Office, 2000.

10 Townsend P, Phillimore P, Beatie A. Health and deprivation: inequality and the north. London: Croom Helm, 1988.

(Accepted 28 November 2003)

\section{bmjlearning.com}

\section{Serious communicable diseases}

BMJ Learning offers online learning resources to train and test your skills in a variety of topics. We have recently published a new module, "Serious communicable diseases: an update on clinical and ethical issues."

Many misunderstandings about serious communicable diseases persist. Patients worry whether they could infect other people and whether they will be shunned if people find out that they have a communicable disease. Patients understandably expect the highest standards of confidentiality from their doctor in these circumstances, and they expect to be told if their doctor is going to test for such diseases.
In addition to these concerns, doctors worry about what would happen if they had a needlestick injury when caring for patients with serious communicable diseases. What should they do there and then? And what would be the long term implications for their health and work?

To get advice on what to do in situations like this and to find out more about ethical and clinical dilemmas that can arise, try our new learning module on bmjlearning.com

Kieran Walsh editorial registrar, BMJ Learning (bmjlearning@bmjgroup.com) 